\title{
ENZYMATIC PARAMETERS AT ADMISSION AND THE RISK OF DEATH IN POLITRAUMA PATIENTRS WITH ASSOCIATED THORACIC TRAUMA
}

\section{Tase Ghinguleac Gristina1, Tudoran Rodica1, Ghirila Sergiu², Gurgas Leonard², Ion lleana²}

${ }^{1}$ County Clinical Emergency Hospital of Constanta

${ }^{2}$ Faculty of Medicine, University "Ovidius" of Constanta

\begin{abstract}
Polytrauma patients represent one of the most challenging medical conditions. Developing methods of assessing the risk of death in these patients is a continous effort for the medical field. In this study we evaluate the creatine kinaze isoenzyme $M B(C K-M B)$ and troponin as markers of increased risk of death in the first 24 hours after admission in polytrauma patients with associated thoracic trauma.

The study was conducted on 33 patients treated in the emergency department of County Clinical Emergency Hospital Constanta between 2014 and 2017.

The results of the study suggest that $C K-M B$ does not offer additional information related to the risk of death in these patients, while in the case of troponin, higher values were observed in the patients that didn't survive after 24 hours of followup.
\end{abstract}

Keywords: cratine kinaze MB, troponin, politrauma, thoracic trauma

\section{Introduction}

One of the most chalenging emergency is polytrauma patients, being an important cause of mortality and morbidity (1). Objective methods that allow for ways of assesing the risk the patients have, especially in the first hours after the event that produced the trauma is crucial in the management of these patients.

For these patients, different scores are used in practice in order to determine their risk, lice Glasgow Coma Score (2), Injury Severity Score (3), Revised trauma score (4) or the new trauma score (5), The acute physiology and chronic health evaluation II (6) or the sequential organ failure assesment (7). While they offer great support for the doctors and standardise the therapeutic approach, the addition of new methods of assessing the risk of the patients with multiple trauma, and in particular with multiple trauma with associated thoracic trauma can offer valueable information.

In this study, we analyze the potential of creatin kinaze MB isoenzyme and troponin to be used as paraclinical tests at the initial evaluation of the polytrauma patients, with thoracic trauma, in determining the risk of death within the first 24 hours after admission. 


\section{Material and method}

We studied 33 patients with severe thoracic polytrauma, admitted through the emergency room of County Clinical Emergency Hospital Constanta between 2014 and 2017.

Inclusion criteria were age - over 16 years old, diagnosis of major polytrauma with thoracic trauma. We excluded from the study patients for whom information about the mechanism of trauma was unknown of a medical background was impossible to obtain.

We compared the values, at admission, for creatine kinaze $\mathrm{MB}$ isoenzyme (CK-MB) and troponin between patients that survived 24 hours after admission and patients the died during the same period of time.

In order to determine the statistical tests to run (parametric or nonparametric), we assesed the normality of the data by observing the histogram and running the Shapiro-Wilk test. Depending on the results, we ran t test or Mann-Whitney U test to compare the values among the two groups of patients.

After comparing the values, we decided to run a second type of test in which we transformed the data according to existing literature, considering the CK-MB cutoff point as being 24 $\mathrm{UI} / \mathrm{L}$, and in the case of troponin as negative for values less between 0 and $0.02 \mathrm{ng} / \mathrm{mL}$, Positive + for values $0.021-0.06 \mathrm{ng} / \mathrm{mL}$, Positive ++ for values between 0.061 and $0.22 \mathrm{ng} / \mathrm{mL}$, and Positive +++ vor values above 0.22 . After the transformation we ran Chi-square test for testing the association between the patients status after 24 hours and enzymes values.

For all statistica tests, we considered the result as being staitstically significant for $\mathrm{p}$ values less or equal to 0.05 .

\section{Results}

From the sample of 33 patients, 11 died in the first 24 hours, while 22 survived. The average age in the survivors group was 48.73 years, with standard deviation of 14.01 and median value of 50. For the group of patients that died within 24 hours after admission, the average age was 50.64 years, with standard deviation of 12.37 and median value of 57 . The difference was not staitstically significant $(p=0.704)$. For both groups, males represent most of the patients, 16 patients $(72.7 \%)$ being males in the survivors group and 9 patients $(81.8 \%)$ being males in the group of the deceased patients. The is no staitstically significant difference according to gender distribution between the groups $(p=0.566)$.

\section{Creatine kinaze MB (CK-MB)}

Analysing the CK-MB values, we observed the fact that average values in the case of deceased patients is more than double when compared to patients that survived (248 U/L compared to 106,64 U/L), while the median was similar, 60 UI/L (Table 1).

Table 1 Descriptive staitstical analysis for $C K-M B$ betwen the two groups

\begin{tabular}{|l|r|r|r|}
\hline & \multicolumn{3}{|c|}{ Died within 24 hours of admission } \\
\hline & \multicolumn{1}{|c|}{ No } & \multicolumn{1}{c|}{ Yes } & \multicolumn{1}{c|}{ Total } \\
\hline $\mathrm{N}$ & 22 & 11 & 33 \\
\hline Mean & 106.64 & 248.00 & 153.76 \\
\hline Standard deviation & 106.844 & 262.20 & 183.18 \\
\hline Median & 60.00 & 60.00 & 60.00 \\
\hline Variance & 11415.576 & 68751.00 & 33555.75 \\
\hline Skewness & 1.392 & .699 & 1.64 \\
\hline Kurtosis & .850 & -1.32 & 1.92 \\
\hline Minimum & 19 & 20 & 19 \\
\hline Maximum & 350 & 700 & 700 \\
\hline
\end{tabular}

The Shapiro-Wilk test had statistically significant results, with $\mathrm{p}$ values less than 0.001 for both groups (Table 2). In figure 1 we represent the distribution of the patients according to CKMB values. We noted that most of the patients have values less than $50 \mathrm{UI} / \mathrm{L}$, summing up to $36 \%$ of the deceased patients and $41 \%$ of the patients in the survivors group. Based on the results of the test and the observation of the histogram, we concluded that the data does not follow a normal distribution, therefore, for comparison, we used nonparametric tests.

Table 2 Shapiro-Wilk test for $C K-M B$

\begin{tabular}{|l|l|l|l|l|l|l|l|}
\hline $\begin{array}{l}\text { Died within 24 hours } \\
\text { of admission }\end{array}$ & \multicolumn{3}{|l|}{$\begin{array}{l}\text { Kolmogorov- } \\
\text { Smirnova }\end{array}$} & \multicolumn{3}{l|}{ Shapiro-Wilk } \\
\hline \multicolumn{2}{|l|}{} & Statistic & df & Sig. & Statistic & df & Sig. \\
\hline \multirow{2}{*}{$\begin{array}{l}\text { CK-MB at } \\
\text { admission }\end{array}$} & Yo & 271 & 22 & .000 & .775 & 22 & .000 \\
\cline { 2 - 8 } & Yes & .309 & 11 & .004 & .803 & 11 & .010 \\
\hline
\end{tabular}




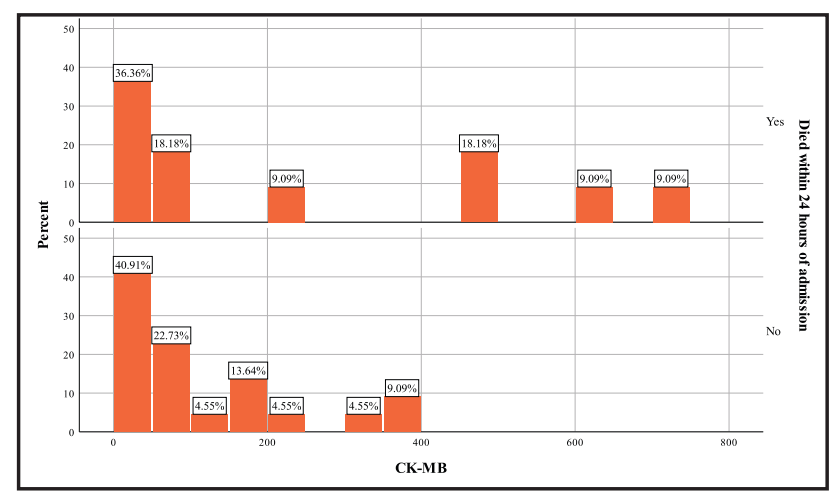

Figure 1 Distribuția valorilor CK-MB la internare comparativ în funcție de evoluția pacienților

Ranks test (Table 3) indicates that the mean range is significantly higher for deceased patients group, with a value of 19.64, while for the survivors is 15.98. This indicates, once more, that patients that died had higher values of CKMB compared to the survivors.

\section{Table 3 CK-MB Ranks}

\begin{tabular}{|l|l|r|r|c|}
\hline & $\begin{array}{c}\text { Died within 24 } \\
\text { hours of admission }\end{array}$ & N & $\begin{array}{c}\text { Mean } \\
\text { Rank }\end{array}$ & $\begin{array}{c}\text { Sum of } \\
\text { Ranks }\end{array}$ \\
\hline \multirow{2}{*}{$\begin{array}{l}\text { CK-MB at } \\
\text { admission }\end{array}$} & No & 22 & 15.68 & 345.00 \\
\cline { 2 - 5 } & Yes & 11 & 19.64 & 216.00 \\
\cline { 2 - 5 } & Total & 33 & & \\
\hline
\end{tabular}

The result of the test was not significant $(\mathrm{z}=-1 / 101, \mathrm{p}=0.268)$ (Table 4)), suggesting that there is no statistically significant difference between the two groups when comparing the CK-MB values.

Table 4 Mann-Whitney $U$ test for $C K-M B$

\begin{tabular}{|l|r|}
\hline & CK-MB at admission \\
\hline Mann-Whitney U & 92.000 \\
\hline Wilcoxon W & 345.000 \\
\hline Z & -1.109 \\
\hline Asymp. Sig. (2-tailed) & .268 \\
\hline Exact Sig. [2*(1-tailed Sig.)] & $.281^{1}$ \\
\hline
\end{tabular}

\section{Association between CK-MB at admission and risk of death}

From the total of 11 patients that died during the first 24 hours after admission, one patients had normal values of CK-MB, while 10 of them had elevated values. At the same time, among the 22 patients that survived after the first 24 hours after admission, 3 had normal values and 19 elevated values. Thus, the percentages of patients with normal values were $13.6 \%$ in the survivors group and $9.1 \%$ in the deceased group
(Table 5)

Table 5 Patients evolution and $C K-M B$ category crosstabulation

\begin{tabular}{|c|c|c|c|c|c|}
\hline & \multicolumn{2}{|c|}{$\begin{array}{l}\text { Died within } \\
24 \text { hours of } \\
\text { admission }\end{array}$} & \multirow[t]{2}{*}{ Total } \\
\hline & & & No & Yes & \\
\hline \multirow{4}{*}{$\begin{array}{l}\text { CK-MB } \\
\text { category }\end{array}$} & & Counts & 3 & 1 & 4 \\
\hline & Normal & $\begin{array}{l}\text { \% din Died } \\
\text { within } 24 \\
\text { hours of } \\
\text { admission } \\
\end{array}$ & $13.6 \%$ & $9.1 \%$ & $12.1 \%$ \\
\hline & & Counts & 19 & 10 & 29 \\
\hline & Elevated & $\begin{array}{l}\% \text { din Died } \\
\text { within } 24 \\
\text { hours of } \\
\text { admission } \\
\end{array}$ & $86.4 \%$ & $90.9 \%$ & $87.9 \%$ \\
\hline \multirow{2}{*}{\multicolumn{2}{|c|}{$\begin{array}{l}\text { Total } \\
\% \text { din Died } \\
\text { within } 24 \text { hours } \\
\text { of admission }\end{array}$}} & Counts & 22 & 11 & 33 \\
\hline & & $100.0 \%$ & $100 \%$ & $100 \%$ & \\
\hline
\end{tabular}

By running the Chi-Square test, the result is not statistically sgnificant $(p=0.7)$, indicating the lack of association between CK-MB category and risk of death.

\section{Troponin}

For troponin, mean values for deceased patients were $1.24 \mathrm{ng} / \mathrm{mL}$, wih a standard deviation of $1.66 \mathrm{ng} / \mathrm{mL}$. For patients that survived, the mean values for troponin were 0.039 $\mathrm{ng} / \mathrm{mL}$, with a standard deviation of $0.063 \mathrm{ng} /$ $\mathrm{mL}$. Meadian values are significantly different, with $0.012 \mathrm{ng} / \mathrm{mL}$ for surviving patients and 0.73 $\mathrm{ng} / \mathrm{mL}$ for deceased patients (Table 6).

Table 6 Descriptive statistics for troponin

\begin{tabular}{|l|r|r|r|}
\hline \multirow{2}{*}{} & \multicolumn{3}{|c|}{ Died within 24 hours of } \\
\cline { 2 - 4 } & \multicolumn{1}{|c|}{ admission } & \multicolumn{1}{c|}{ No } & \multicolumn{1}{c|}{ Total } \\
\hline $\mathrm{N}$ & 22 & 11 & 33 \\
\hline Mean & .03955 & 1.24055 & .43988 \\
\hline Standard Deviation & .06287 & 1.6667 & 1.09605 \\
\hline Median & .01200 & .07300 & .03000 \\
\hline Variance & .004 & 2.778 & 1.201 \\
\hline Skewness & 2.109 & .722 & 2.482 \\
\hline Kurtosis & 3.750 & -1.738 & 4.583 \\
\hline Minimum & .000 & .020 & .000 \\
\hline Maximum & .220 & 3.800 & 3.800 \\
\hline
\end{tabular}

According to the result of Shapiro-Wilk test (Table 7) and the histogram (Figure 2), the distribution of troponin values differ in a statistically significant $(p<0.001)$ and graphical 
way from a normal distribution. Therefor, for comparing the values we used the nonparametric

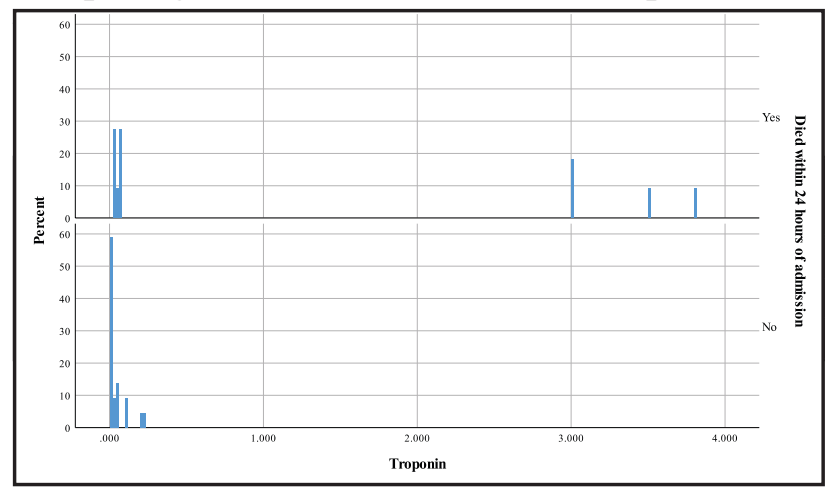

Figure 2 Distribution according to troponin

Graphically, we notice the fact that in the case of deceased patients, none of them have troponin values less than $0.02 \mathrm{ng} / \mathrm{mL}$, while in the case of the patients that survived the first 24 hours, almost $60 \%$ of them have values less than $0.02 \mathrm{ng} / \mathrm{mL}$. Also, in the case of the deceased patients, $36.37 \%$ had values higher than $3 \mathrm{ng} / \mathrm{mL}$.

Comparing the ranks, the average rank in the deceased patients group was 24,41 , singnificantly higer when compared to the survivors group, for which the average rank was 13.3 (Table 8).

Table 8 Troponin ranks

\begin{tabular}{|l|l|l|l|l|}
\hline \multirow{2}{*}{$\begin{array}{l}\text { Died within 24 hours } \\
\text { of admission }\end{array}$} & $\mathrm{N}$ & $\begin{array}{l}\text { Mean } \\
\text { Rank }\end{array}$ & $\begin{array}{l}\text { Sum of } \\
\text { ranks }\end{array}$ \\
\hline \multirow{2}{*}{$\begin{array}{l}\text { Troponin at } \\
\text { admission }\end{array}$} & No & 22 & 13.30 & 292.50 \\
\cline { 2 - 5 } & Yes & 11 & 24.41 & 268.50 \\
\cline { 2 - 5 } & Total & 33 & & \\
\hline
\end{tabular}

The observed difference was statistically significant $(\mathrm{z}=-3.126, \mathrm{p}=0.002)$ (Table 9). This sustains, with a high degree of confidence the fact that patients that survived the first 24 hours after admission had significantly lower values of troponin.

Table 9 Aplicarea testului Mann Whitney-U pentru valorile troponinei în funcție de evoluția pacienților

\begin{tabular}{|l|r|}
\hline & Troponina la internare \\
\hline Mann-Whitney U & 39.500 \\
\hline Wilcoxon W & 292.500 \\
\hline Z & -3.126 \\
\hline Asymp. Sig. (2-tailed) & .002 \\
\hline Exact Sig. [2*(1-tailed Sig.)] & .001 \\
\hline
\end{tabular}

\section{Risk of death according to troponin} values

For estimating the association between troponin category and risk of death, we crostabulated the data. The results, from table 10, shw that in the group of patients that died within 24 hours of admission, all of them were in the category Positive ++ (4 patients) or Positive $+++(7$ patients). In the group of survivors, from the total of 22 patients, 6 were considered to be negative, 7 Positive,+ 5 Positive ++ and 4 Positive +++ .

Table 10 Patients evolution and troponin category crosstabulation

\begin{tabular}{|c|c|c|c|c|c|}
\hline \multicolumn{3}{|l|}{$\begin{array}{l}\text { No } \\
\text { Yes }\end{array}$} & \multicolumn{2}{|c|}{$\begin{array}{l}\text { Died within } \\
24 \text { hours of } \\
\text { admission }\end{array}$} & \multirow{2}{*}{\begin{tabular}{|l} 
Total \\
6 \\
\end{tabular}} \\
\hline \multirow{8}{*}{$\begin{array}{l}\text { Troponin } \\
\text { category }\end{array}$} & & Counts & 6 & 0 & \\
\hline & Negativ & $\begin{array}{l}\% \text { from } \\
\text { Died within } \\
24 \text { hours of } \\
\text { admission }\end{array}$ & $27.3 \%$ & $0.0 \%$ & $18.2 \%$ \\
\hline & & Counts & 7 & 0 & 7 \\
\hline & Positive + & $\begin{array}{l}\% \text { from } \\
\text { Died within } \\
24 \text { hours of } \\
\text { admission }\end{array}$ & $31.8 \%$ & $0.0 \%$ & $21.2 \%$ \\
\hline & & Counts & 5 & 4 & 9 \\
\hline & Positive ++ & \begin{tabular}{|l}
$\%$ from \\
Died within \\
24 hours of \\
admission \\
\end{tabular} & $22.7 \%$ & $36.4 \%$ & $27.3 \%$ \\
\hline & & Counts & 4 & 7 & 11 \\
\hline & $\begin{array}{l}\text { Positive } \\
+++\end{array}$ & \begin{tabular}{|l}
$\%$ from \\
Died within \\
24 hours of \\
admission \\
\end{tabular} & $18.2 \%$ & $63.6 \%$ & $33.3 \%$ \\
\hline \multirow{2}{*}{\multicolumn{2}{|c|}{$\begin{array}{l}\text { Total } \\
\% \text { from Died } \\
\text { within } 24 \text { hours of } \\
\text { admission }\end{array}$}} & Counts & 22 & 11 & 33 \\
\hline & & $100 \%$ & $100 \%$ & $100 \%$ & \\
\hline
\end{tabular}

The graphical representation of the proportion (Figure 3) offer a better insight on the distribution of the patients based on troponin category. 


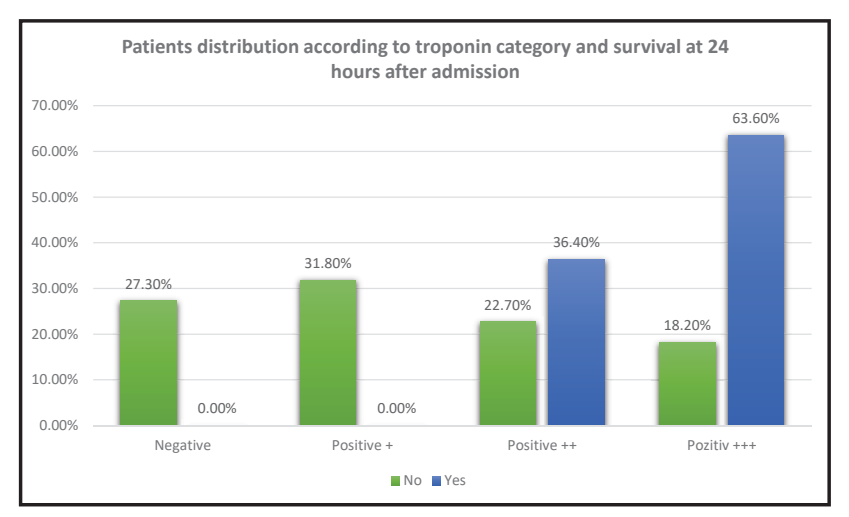

Figure 3 Patients distribution according to troponin category and survival at 24 hours after admission

When applying the chi-square test, the percentage of cells with expected values less than 5 is higher than $20 \%$, therefore, we considered the statistical significance obtained from the Likelihood Ratio, which is 0.002 . This result indicates that there is a significant association between troponin category and risk of death, thus, positioning a patient into Positive ++ or Positive +++ indicates a significantly higher risk of death in the first 24 hours after admission.

Table 11 Chi-square test for troponin

\begin{tabular}{|l|r|r|r|}
\hline & Value & df & \multicolumn{1}{|c|}{$\begin{array}{l}\text { Asymptotic } \\
\text { Significance } \\
\text { (2-sided) }\end{array}$} \\
\hline Pearson Chi-Square & $11.545^{2}$ & 3 & .009 \\
\hline Likelihood Ratio & 15.224 & 3 & .002 \\
\hline N of Valid Cases & 33 & & \\
\hline $\begin{array}{l}\text { a. } 6 \text { cells (75.0\%) have expected count less than 5. The } \\
\text { minimum expected count is 2.00. }\end{array}$ \\
\hline
\end{tabular}

\section{Discussion}

In the case of CK-MB we observed that almost $90 \%$ of all the patients had increased values. Combined with the fact that the percentage of patients with elevated values was almost identical in both groups $(86.4 \%$ vs $90.9 \%$ ), results in the conclusion that CK-MB is not helpful in identifying the risk of death in patients with polytrauma and associated thoracic trauma. Other studies concluded that CK-MB is not useful in determining cardiac injury as it is not specific enough (8).

In the case of troponin, this proved to increase more in patients that didn't survived in the first 24 hours after admission. There are a number of studies that proved the fact that trauma patients with increased troponin values are of greater death risk, representing a real challenge $(9,10)$.

The particularity of this study is the fact that the patients considered have polytrauma with associated thoracic trauma. We didn't tried to identify subsequent organ (cardiac) involvement, as we considered only the main outcome, death within 24 hours of admission as the only objective of this study.

\section{Conclusions}

Increased values of creatine kinase $\mathrm{MB}$ isoenzyme do not associate with higher risk of death, while troponin values suggest to be useful during initial assessment of polytrauma patients with thoracic trauma in identifying patients with increased risk of death.

\section{References}

1. World Health Organization. Global burden of disease. Geneva: WHO Press; 2015.

2. Teasdale G, Jennett B. Assessment of coma and impaired consciousness. A practical scale. Lancet (London, England). 1974;2(7872):81-4.

3. Baker SP, O’Neill B, Haddon W, Jr., Long WB. The injury severity score: a method for describing patients with multiple injuries and evaluating emergency care. J Trauma. 1974;14(3):187-96.

4. Champion HR, Sacco WJ, Copes WS, Gann DS, Gennarelli TA, Flanagan ME. A revision of the Trauma Score. J Trauma. 1989;29(5):623-9.

5. Jeong JH, Park YJ, Kim DH, Kim TY, Kang $\mathrm{C}$, Lee $\mathrm{SH}$, et al. The new trauma score (NTS): a modification of the revised trauma score for better trauma mortality prediction. BMC Surgery. 2017;17(1):77.

6. Knaus WA, Draper EA, Wagner DP, Zimmerman JE. APACHE II: a severity of disease classification system. Critical care medicine. 1985;13(10):818-29.

7. Vincent JL, de Mendonca A, Cantraine F, Moreno R, Takala J, Suter PM, et al. Use of the SOFA score to assess the incidence of organ dysfunction/failure in intensive care 
units: results of a multicenter, prospective study. Working group on "sepsis-related problems" of the European Society of Intensive Care Medicine. Critical care medicine. 1998;26(11):1793-800.

8. Bansal MK, Maraj S, Chewaproug D, Amanullah A. Myocardial contusion injury: redefining the diagnostic algorithm. Emergency Medicine Journal. 2005;22(7):465-9.

9. Mahmood I, El-Menyar A, Dabdoob W, Abdulrahman Y, Siddiqui T, Atique S, et al. Troponin $\mathrm{T}$ in patients with traumatic chest injuries with and without cardiac involvement: Insights from an observational study. North American Journal of Medical Sciences. 2016;8(1):17-24.

10. Lippi G, Buonocore R, Mitaritonno M, Cervellin G. Cardiac Troponin I Is Increased in Patients with Polytrauma and Chest or Head Trauma. Results of A Retrospective Case-Control Study. 2016;35(3):275. 